\title{
Health prevention at school: dilemmas situation and role playing
}

Volume 6 Issue 2 - 2017

\author{
Eric Dugas \\ Université de Bordeaux Chargé de mission, France
}

\section{Opinion}

Health is a subject covering multiple aspects, which admits a various range of representations; but it is now widely considered that health is not limited to physical alterities or diseases, which would refer to a dualism of the past, and thus increase discrimination of any kind. According to the WHO (World Health Organization), «Health is a state of complete physical, mental and social well-being and not merely the absence of disease or infirmity. ${ }^{1}$ " Furthermore, Health lies within elements of subjectivity and relativity.

Yet, youngsters - depending on their life context (intra personal, socio-cultural, economic, family ...) - face many issues decreasing their ability to take care of themselves (addictions, risk-takings, activities at risk, unhealthy diets, lifestyle, etc.). This could be explained through the objective risk, considered as meaningless, mainly because it is not assimilated at that time. This leads to a "time inconsistency": the risk is too distant to be concerned. For example, is it worth to consent to a consequent effort today compared to uncertain future benefits? Uncertain benefit because too far away for the young people to ever hope to reach it. By analogy, this idea can be illustrated through the daily dilemma between instant gratification and that delayed.

The solution would then be to increase the "shadow cast by the future back upon the present"; 1 it is only under this condition that it will be easier to convince students and their families, as well as teachers to combine health with any social practice without any excesses, nor danger to the welfare and "well-becoming" for all. Consequently, educating upon Health will necessarily be through the filter of the "subjective risk", ${ }^{2}$ in order to change youngsters bad habits, eventually their habitus of life, by feeling a bit frightened by the effect of poor health, in its broad sense. This perception will be accomplished through appropriate and controlled educational situations, where the stake - the health capital - is tangible. For example, during a role playing game, ${ }^{3,4}$ or a serious game which aims to develop a relational empathy (social well-being) or within secured situations in vivo by the teacher, but not perceived as such by the student so that they become aware and / or feel the danger (traffic safety, for example).

Those "role played" situations could create greater reflexive analysis by the youngsters and, therefore, short-term decisions more in line with the intended effect as those obtained by a moralizing speech. Thus, we can learn not to play with his health, but it requires steady education, within a dynamic pedagogical approach. Facing this subjectivity, someone's emotions or day-to-day life, the choices are neither often rational nor optimal. We know, thanks to scientific progress, that feelings guide our reason, and our decisions are not always the result of a coherent, conscious and exclusively rational reasoning; reasoning which obeys to hunches, choices, that leads to an increase in risks ... Therefore it is also good to take the chance to dare for oneself and dare to reach out to others. ${ }^{5-7}$

\author{
Correspondence: Éric Dugas, Professeur des universities, \\ Chargé de mission handicap/Université de Bordeaux Chargé de \\ mission, santé/ESPE d $\square$ Aquitaine, LACES EA 4I40, France, \\ Email eric.dugas@u-bordeaux.fr
}

Received: January 28, 2017 | Published: February 13, 2017

${ }^{1}$ Preamble to the Constitution of WHO as adopted by the International Health Conference, New York, 19 June - 22 July 1946; signed on 22 July 1946 by the representatives of 61 States (Official Records of WHO, no. 2, p. 100) and entered into force on 7 April 1948. The definition has not been amended since 1948 .

\section{Acknowledgments}

None.

\section{Conflicts of interest}

Author declares there are no conflicts of interest.

\section{Funding}

None.

\section{References}

1. Axelrod R. Comment réussir dans un monde d'égoïstes. Théorie du comportement coopératif. Paris: Odile Jacob. 2006;[1984].

2. Dugas E. Sport et santé: oui, mais de quel(s) sport(s) parle-t-on?. In Monnin E. Ferréol G. (dir.), Sport, santé et cohésion sociale, Belfort : Université de technologie de Belfort- Montbéliard. 2014. p.53-63.

3. Tisseron S. L'empathie au cœur du jeu social, Paris: Albin Michel. 2010.

4. Loyer F, Dugas E. Le catch en EPS : une pratique physique originale adaptée aux élèves? eJRIEPS. 2014;32:38-71.

5. Dugas E, Ferréol G. Oser l'autre. Altérités et éducabilité dans la France contemporaine. Bruxelles, Éd. Inter Communication. 2015.

6. Dugas E, Rollin Z. La question des formations initiale et continue des enseignants au profit des élèves en situation de handicap. Revue de Santé Scolaire \& Universitaire. 2014;39: 29-33.3.

7. Dugas E. Association Européenne pour l'Enseignement de la Pédiatrie 2013 